\title{
Autoimmunity in inflammatory bowel disease
}

\author{
KIRON M DAS, MD, PHD, FRCP, FACP
}

\begin{abstract}
KM DAS. Autoimmunity in inflammatory bowel disease. Can J Gastroenterol 1993;7(2):102-109. Autoimmune injury to the colonic epithelium has been a favoured hypothesis ever since circulating anticolon antibodies were first demonstrated in patients with inflammatory bowel disease (IBD). There is some evidence that anticolon antibodies present in the sera from patients with ulcerative colitis, but not Crohn's disease, may injure epithelial cells by antibody-dependent cellular cytotoxicity (ADCC). The ADCC correlated with the disease state in ulcerative colitis and disappeared following total colectomy-Recent studies also demonstrated specific immunoglobulin (Ig) $\mathrm{G}$ deposition along with activated complement components on colonic epithelium in ulcerative colitis and not in Crohn's disease, suggesting a role of anti-epithelial antibody causing cellular damage. The mucosal B cells in ulcerative colitis produce anticolon antibodies. Antineutrophil cytoplasmic antibody in patients with ulcerative colitis is intriguing and identification of the immunoreactive antigen from the neutrophils may explain its association with ulcerative colitis. Detection of intestinal mucosal T cells reactive against epithelial cell-associated components also supports the existence of cytotoxic cells aimed at intestinal cells. The isolation of colon-bound $\operatorname{lgG}$ antibody in ulcerative colitis directed towards a unique colonic antigen, molecular weight fraction $(\mathrm{Mr}) 40 \mathrm{~K}$ protein (P-40) suggests a specific form of autoimmunity in ulcerative colitis. P-40 is expressed in colonic epithelium and not in 13 other epithelial organs including other parts of the gastrointestinal tract, However, extraintestinal organs such as skin and biliary epithelium (organs commonly affected in ulcerative colitis) have a unique epitope shared with colonic epithelium. Anti-P-40 antibodies are present in the circulation of patients with ulcerative colitis and peripheral blood lymphocytes show proliferative response to the colon extract enriched in P-40. Recent studies demonstrated amplified IgG1 antibody in the circulation (as well as in situ) bound to the colonic mucosal epithelium along with activated complement products in patients with ulcerative colitis and not in Crohn's disease. This IgG1 autoantibody response appears to be predominantly directed to P-40. (Pour résumé, voir page 103)
\end{abstract}

Key Words: Autoimmunity, Crohn's disease, Inflammatory bowel disease, $\mathrm{Mr} 40 \mathrm{~K}$ protein, Ulcerative colitis

University of Medicine and Dentistry of New Jersey, Robert Wood Johnson Medical School, New Brunswick, New Jersey

Correspondence and reprints: Dr KM Das, University of Medicine and Dentistry of New Jersey, Robert Wood Johnson Medical School, 1 Robert Wood Johnson Place - CN 19, New Brunswick, New Jersey 08903, USA, Telephone (908) 937-7784.
$\mathrm{T}$ HE IDEA THAT INFLAMMATORY bowel disease (IBD) might be some form of an autoimmune disease has been under consideration ever since the initial report of the presence of circulating anticolon antibodies in 1959 (1). This idea is particularly attractive in relation to ulcerative colitis which is confined to the colonic epithelium. Although both Crohn's disease and ulcerative colitis are two well defined and distinct entities, they are commonly referred to as a single entity, IBD. Several recent reviews have discussed various immunological aspects and their possible roles in the pathogenesis of IBD $(2-4)$. This review will focus on some of the recent advances in understanding of the general autoimmune reactions in human dis. eases, with particular attention to IBD.

Major histocompatibility antigens class II molecules and $\mathrm{T}$ cell recogni. tion for autoimmune reactions: Major histocompatibility antigens (MHA) molecules are cell-surface molecules in. volved in cell-cell recognition and im. munologic signalling events. Class I molecules are present on nucleated cells and are involved in the presenta. tion of cell-surface-associated antigens, such as viruses. Cytotoxic/suppressor (CD8) T cells recognize cell-surface an. tigens in conjunction with class ! molecules. This is one of the important mechanisms of elimination of virus in. 


\section{Auto-immunité dans la maladie inflammatoire de l'intestin}

RÉSUMÉ: Les lésions auto-immunes de l'épithélium colique ont été une hypothèse populaire depuis la découverte d'anticorps anticoliques circulants chez des patients atteints de maladie inflammatoire de l'intestin. Selon certains résultats, la présence d'anticorps anticoliques dans le sérum de patients atteints de colite ulcéreuse et non pas de maladie de Crohn, pourrait endommager les cellules épithéliales par un mécanisme de cytotoxicité cellulaire liée aux anticorps. Ce phénomène concordait avec l'étendue de la colite ulcéreuse et a disparu après la colectomie totale. Des études récentes ont également démontré des dépôts d'immunoglobuline $\lg (G)$ spécifique avec des éléments du complément activé sur l'épithélium colique dans la colite ulcéreuse et non pas dans la maladie de Crohn, suggérant le rôle d'anticorps anti-épithéliaux provoquant une lésion cellulaire. Les cellules B muqueuses dans la colite ulcéreuse produisent des anticorps anticôlon. Les anticorps cytoplasmiques antineutrophiles chez les patients porteurs de colite ulcéreuse sont intéressants et l'identification de l'antigène immuno-réactif des neutrophiles pourrait expliquer son association avec la colite ulcéreuse. Le dépistage de cellules $T$ de la muqueuse intestinale qui réagissent contre des éléments associés aux cellules épithéliales, appuie également l'existence d'élément cytotoxiques à l'égard des cellules intestinales. L'identification d'un anticorps IgG lié au côlon dans la colite ulcéreuse, dirigé contre un antigène colique unique, la protéine $40 \mathrm{~K}(\mathrm{P}-40)$, suggère une forme spécifique d'auto-immunité dans la colite ulcéreuse. P-40 est exprimé dans l'épithélium colique et non pas dans les 13 autres organes épithéliaux, y compris d'autres portions des voies digestives. Cependant, les organes extra-intestinaux comme la peau et l'épithélium iléal (organes fréquemment affectés dans la colite ulcéreuse) ont un déterminant génétique unique partagé avec l'épithélium colique. Les anticorps anti-P-40 sont présents dans la circulation des patients atteints de colite ulcéreuse et les lymphocytes sanguins périphériques montrent une réponse proliférative aux extraits coliques enrichis en P-40. Des études récentes ont démontré des anticorps IgG1 accrus dans la circulation (et in situ) liés à l'épithélium muqueux du côlon avec des produits du complément activé chez les patients atteints de colite ulcéreuse et non pas de maladie de Crohn. Cette réponse immunitaire IgG1 semble être surtout dirigée contre P-40.

fected cells. Class II molecules are present on a variety of cell types, especially the antigen presenting cells, and play a critical role in autoimmunity.

The minimal requirement for activation of the helper $\mathrm{T}\left(\mathrm{T}_{\mathrm{H}}\right)$ lymphocytes (CD4) is the interaction of their T cell receptors with fragments of processed antigen (foreign or autoontigen) expressed along with class II MHA molecules on the cell surface of antigen presenting cells (Figure 1). This interaction between $T$ cells and antigen presenting cells is facilitated by the CD4 molecule, which binds to MHA II. Class II molecules are encoded by DP, DQ, and DR genes of the human lymphocyte antigen (HLA) complex in man. The immune system can respond to a wide variety of different protein antigens, and any one MHA molecule can associate with a vast assortment of antigenic structures.
MHA molecules are highly polymorphic, and products of separate alleles can associate with different sets of peptide antigenic structures. Following recognition of the antigen(s), $T$ cells become activated and express additional surface molecules, eg, interleukin-2 receptors (IL-2R), which are not seen in resting $\mathrm{T}$ lymphocytes. These cellular events result in the production of various cytokines including IL-1, IL-2, tumour necrosis factor, and interferongamma, which may enhance or inhibit immune responses. Based on this knowledge, CD4, T cell receptors, IL-2R, MHA II and many cytokines may be considered potential targets for imnunosuppressive therapy in autoimmune diseases, including IBD. Indeed, in a recent report chimeric monoclonal anti-CD4 antibody treatment was found to be effective for treating both ulcerative colitis and Crohn's disease.
Expression of MHA II antingens in the gastrointestinal tract: In an attempt to map out the expression of MHA class II antigens in normal human tissue, Daar and co-workers (6) used monoclonal antibodies to demonstrate that MHA class II antigens were present in the duodenum, ileum and appendix of the gastrointestinal tract. Class II antigens were not, however, present in normal esophagus, stomach, colon or rectum. Selby and co-workers (7), in addition to confirming that normal colon epithelium did not bear MHA-DR antigens, found that nine of 13 active ulcerative colitis specimens and 11 of 12 active Crohn's colitis specimens exhibited strong colon epithelial cell MHA-DR staining.

More recent studies using immunoelectromicroscopy have demonstrated that MHA-DR antigens are also present on lamina proyria macrophages, lymphocytes, dendritic cells, fibroblasts, vascular endothelial cells and lymphatic endothelial cells (8). In IBD specimens, staining was strongest on basal and lateral epithelial cell surfaces with less microvillus staining.

The recognition of the antigen $(\mathrm{s})$ in conjunction with self MHA-DR molecules in intestinal epithelium (or other target cells) allows a population of $\mathrm{T}$ cells $\left(T_{H}\right)$ activated to recognize the same antigen(s) presented by selfMHA-DR components at a future time. The activated $T_{H}$ cells can generate cytotoxic $T$ lymphocytes and can stimulate the B cells to produce specific antibodies against epithelial cell associated protein(s) (Figure 2).

Immunogenetics: Evidence to support a genetic basis for an autoimmune disorder includes familial clusters of disease and autoantibodies, a high rate of concordance in identical twins, and linkage with a known genetic locus - in particular, class I or class II gene products of the major histocompatibility complex (9). Clusters of cases of inflammatory bowel disease within families have been reported in 17\% to $39 \%$ of index cases in large series and, as reviewed by Klein and colleagues (10), a high concordance rate in identical twins has been found. Linkage disequilibrium in chronic IBD has not 


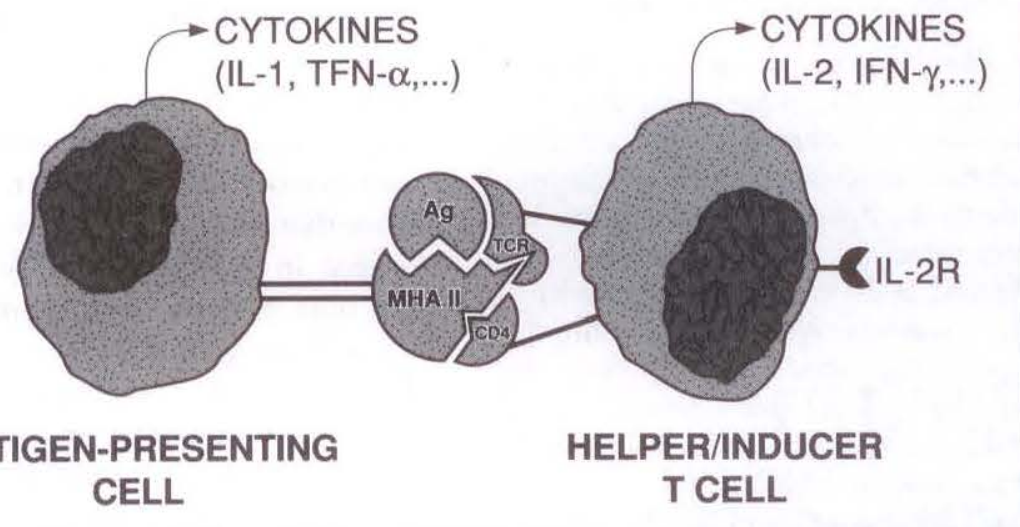

Figure 1) Recognition by helper/inducer $T$ cells of processed antigen (Ag) in association with class 11 major histocompatibility antigens (MHA-II) on antigen presenting cells (APC)

been found to occur, although lack of an association with class II antigens may simply reflect the microheterogeneity of DR and other genes (11). A recent study using an ethnically matched population observed more frequent association of ulcerative colitis with HLA-DR2 and for Crohn's disease a somewhat weaker linkage with DR1DQw5 (12). Absence of a strong genetic basis for IBD or any human autoimmune disease, and the presence of autoantibodies in apparently healthy family members (13), may suggest that inheritance of two or more unlinked functional classes of genes may be necessary for disease to occur. One gene may permit the formation of autoantibodies through a defect in immunoregulation, whereas the other may allow the development of lesions, through a disorder in the immune system's effector arm (9).

Anticolon antibodies: The initial finding of anticolon antibodies (1) has been confirmed by many investigators $(14,15)$. These anticolon antibodies are present in many but not all patients with IBD; they are equally common in ulcerative colitis and Crohn's disease, but cross react with enterobacterial common antigen (16) and with human blood group $\mathrm{ABH}$ antigens; they do not correlate with disease activity, duration or extent. There was no evidence of binding of these anticolon antibodies with intestinal tissue in vivo and they do not mediate complement lysis of cells or antibody-dependent cell- mediated cytolysis (ADCC). They were also found in several illnesses other than IBD that do not have intestinal involvement. The antigen recognized by serum from patients with IBD is a lipopolysaccharide extractable from human fetal colon (1), germ-free rat colon or feces; the latter materials have frequently been substituted for human material in assays. The colon lipopolysaccharide antigen is related to, but is distinct from, the common enterobacterial antigen of Kunin. One inherent problem with these serum anticolon antibodies has been the question of whether they have anything to do with the initiation or pathogenesis of the disease in the intestinal mucosa.

More recent studies, however, demonstrated the presence of disease specific antibodies in IBD (17-21). Using double colour immunofluorescence, deposition of specific IgG, together with activated complement products along the apical aspects of the colonic epithelial cells and a predominant corresponding subclass bearing B cells in the lamina propria in patients with ulcerative colitis, were demonstrated (22). In Crohn's disease the antibody response was mainly $\operatorname{lgG} 2$ and a different pathway of activation of complement was noted (23). The mechanism of these specific IgG responses, in particular the antigen(s) involved to initiate these responses, and the precise role of these antibodies are unknown. Complement activation as shown in both ulcerative colitis (22) and Crohn's disease (23), with release of $\mathrm{C} 3 \mathrm{~b}$ and $\mathrm{C} 5 \mathrm{a}$ molecules may cause migration of neutrophils, macrophages and other effector cells by chemotaxis (Figure 3). Such influx and activation of the effector cells can cause release of leukotrienes, prostaglandins, platelet activating factor, oxygen radicals and proteases which lead to inflammatory response and epithelial cell destruction. Specific antibodies binding to the antigenic molecules on the target cells may also initiate ADCC, causing cytolysis as shown in ulcerative colitis $(17,20)$.

Specific epithelial antigens: Isolation of specific cellular components and tissue-bound antibodies against the specific tissue components have contributed to understanding of the pathogenesis of other diseases of chronic nature and unknown etiology considered to be 'autoimmune' (24-27). A hypothesis that presently enjoys much popularity among clinical im. munologists is that of 'molecular mimicry' associated with a 'hit-and-run event' (28). In this concept, a primary agent, such as a virus, a bacterium of foreign protein, may attack a specific organ, triggering a local immune response directed against the aggressor. This noxious offender may be eliminated or destroyed, but in doing so the immune system is forced to produce antibodies or generate cells sensitized to some of the offender's antigens (pep. tides) which share the same molecular configuration with components of the host's tissues (molecular mimicry) (Fig. ure 2 ). As a consequence, the immune system is now able to recognize and attack normal cells, triggering an autoaggressive reaction even though the initial culprit has completely disap. peared (hit-and-run event). This theory has been suggested to explain some diseases such as gluten-sensitive enteropathy, ankylosing spondylitis, and Reiter's syndrome and autoimmune myocarditis, based on evidence of molecular mimicry of the wheat protein A-gliadin with the ElB protein of the human adenovirus Ad-12 for celiac disease (29), the HLA-B27 allele with Klebsiella pneumoniae nitrogenase for the above mentioned arthropathies 


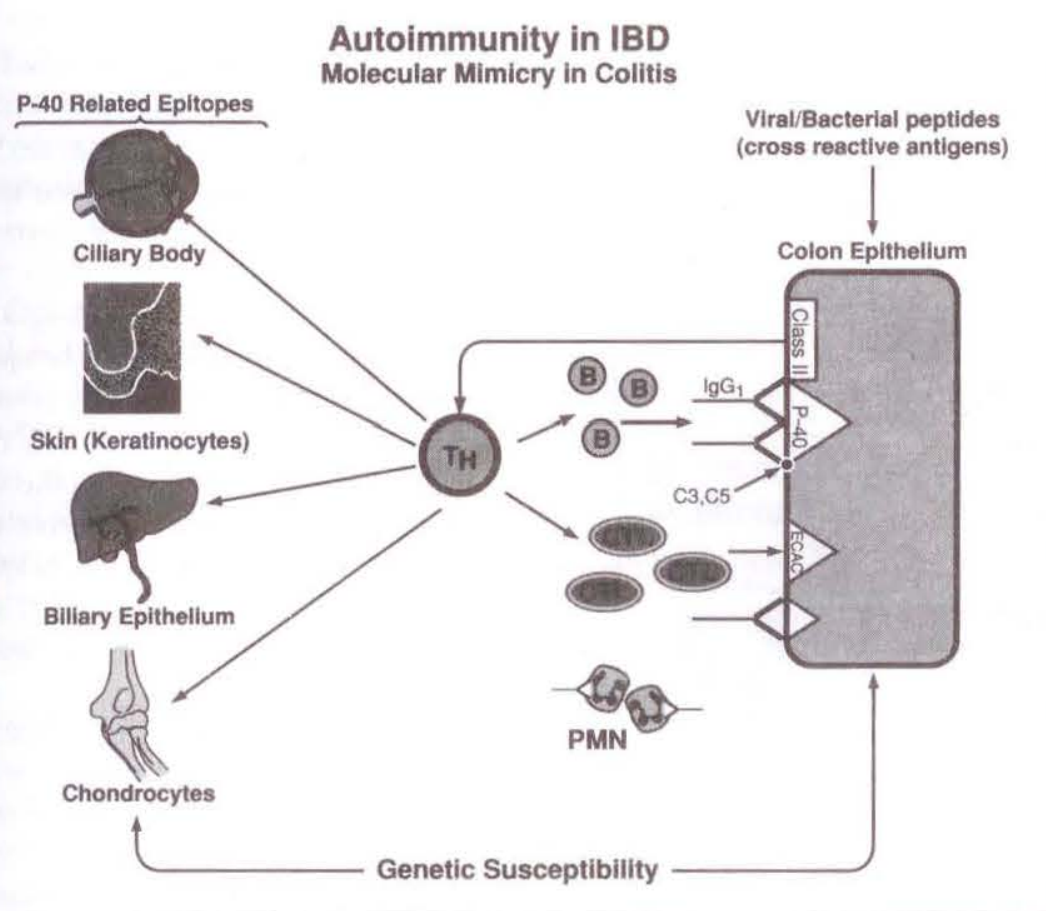

Figure 2) An outline of proposed molecular mimicry involving $\mathrm{Mr} 40 \mathrm{~K}$ protein (or ECAC-C) and the expression of crossreactive unique epitope(s) related to $\mathrm{Mr} 40 \mathrm{~K}$ protein in extraintestinal organs known to be involved in colitis. CTL Cytotoxic lymphocyte

(30), and cardiac muscle tropomyosin with streptococcal M-protein for autoimmune myocarditis (31). Similar mechanisms may be involved in IBD. However, in IBD, neither the triggering agent(s) inciting the autoimmune reaction nor the precise cellular epitopes, the target molecules, are known. Several candidate antigens more specific to IBD have been proposed.

The isolation of purified and well characterized intestinal antigens has added more scientific credibility to the investigation of autoimmune phenomena in IBD during the last several years $(13,18,19)$. Similarly, the detection of intestinal mucosal $\mathrm{T}$ cells reactive against gut-specific epithelial cell associated proteins also lend support to the existence of cytotoxic cells aimed at intestinal cells $(32,33)$.

In earlier studies, cells cytotoxic for colonic epithelial cells were first found in the peripheral blood of patients with ulcerative colitis $(34,35)$ and subsequently in Crohn's colitis (36). The existence of such cells raised the possibility that a cellular autoimmune reaction to the colonic epithelium may be involved in the pathogenesis of IBD. This is an attractive hypothesis to explain why ulcerative colitis remains confined to the colonic mucosa. Lack of long term cultures of human colonic epithelial cells and adult colonic epithelial cells freshly isolated by trypsinizing minced colonic mucosa with a limited life span have greatly limited the numbers of studies in this area. The cell mediating this cytotoxicity was thought to be killer cell or the natural killer cell subset $(37,38)$. Thus, the cytotoxicity represents either ADCC or natural killer cell cytotoxicity. This is consistent with the observation that a high molecular weight factor is in the serum of patients with IBD that can induce cytotoxicity in lymphocytes of normal individuals (39). Although this material has never been conclusively identified, it is thought to be some type of cytophilic antibody or small immune complexes that 'arms' the killer cells. A similar type of cytotoxicity was identified in the lamina proprial cells of patients with IBD (38).

Intestinal epithelial cell-associated components: Intestinal epithelial cell associated components (ECAC) antigens described by Roche and colleagues (13) are associated with both ulcerative colitis and Crohn's disease. Using an ADCC assay with chicken erythrocytes coated with ECAC of colonic origin (ECAC-C) and human sera, it was found that prevalence of antibodies to ECAC-C was $69.7 \%$ among patients with chronic IBD, both ulcerative colitis and Crohn's disease, and 55.7\% among relatives; both prevalences were significantly higher than that of the control group $(8.0 \%, \mathrm{P}<0.001)$. Using small-bowel-derived ECAC, the prevalence of antibodies among patients with IBD and relatives was also significantly higher than that of controls. Reactivity of sera was directed to a 160 - and a 137-KDa macromolecule.

Crohn's disease-associated tissue antigens and mycobacterial antigens: Glycoproteins extracted from Crohn's disease tissue were recognized by Crohn's disease sera more significantly $(\mathrm{P}<0.01)$ when compared with sera from disease controls or with normal tissue extracted glycoproteins $(\mathrm{P}<0.0005)$ (40). To identify the immunoreactive proteins, Crohn's disease tissue proteins were immunoprecipitated with Crohn's disease sera, and three major proteins of relative molecular weight $-160,000,120,000$ and 110,000 - were detected (41). Using immunotransblot experiments, two glycoproteins associated with Crohn's disease tissue of approximate molecular weight 200,000 and 160,000 were subsequently identified (42). These proteins reacted with Crohn's disease sera but not with ulcerative colitis or other control sera. The source of these immunoreactive proteins and their role in Crohn's disease is unknown. A recent study demonstrated the presence of circulating antibody in two-thirds of the patients with Crohn's disease against a mycobacterial $45 / 48 \mathrm{kDa}$ doublet antigen (43). There was a positive correlation of the antibody titre with activity of the disease. It is unclear whether mycobacterial antigens are etiologically involved in Crohn's disease or if this is a molecular mimicry response. 


\section{IgG-Mediated Cellular Injury}

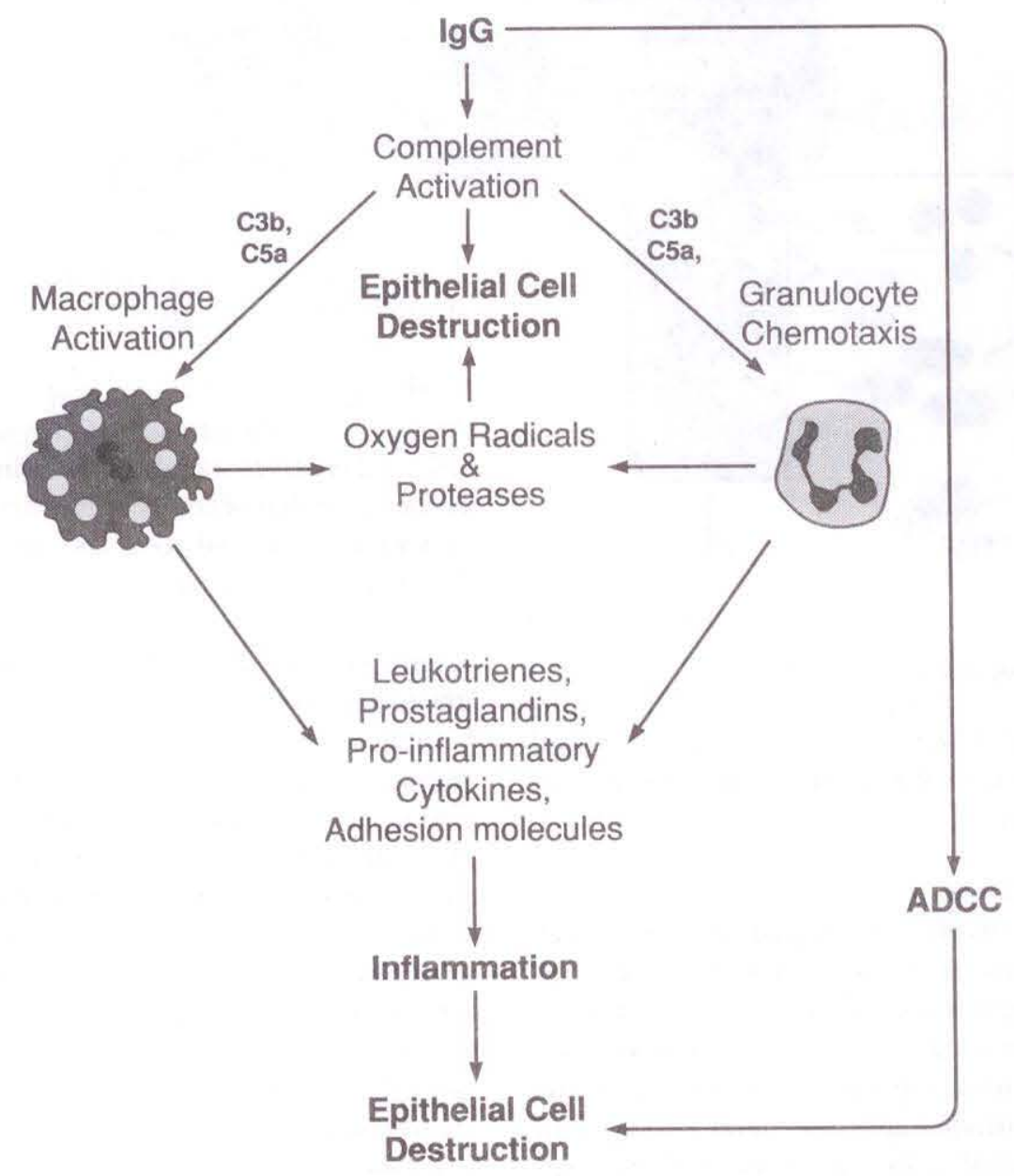

Figure 3) Sequence of events for cellular injury and inflammation that may occur following the binding of IgG to the cellular antigen(s)

Anticolon antibody production by mucosal and peripheral blood lymphocytes in ulcerative colitis: Using ulcerative colitis serum antibody and isolated rat colon epithelial cells, Hibi et al (5) found the frequency of serum anticolon antibody to be $71 \%$ in 41 patients with ulcerative colitis. When Epstein-Barr virus was used as a B cell polyclonal activator, they further demonstrated the frequencies of $\lg G$ anticolon antibody secreting $B$ cells to be 1.5 to $12.5 / 10^{6}$ cells in the colonic mucosa and 0.1 to $0.5 / 10^{6}$ cells in peripheral blood, from patients with ulcerative colitis. Although the nature of the antigens recognized by these an- tibodies are unknown, they are localized in the colon epithelial cells.

Perinuclear antineutrophil-cytoplasmic antibody: Recently perinuclear antineutrophil-cytoplasmic antibody (PANCA) has been detected in the sera of the majority of patients with ulcerative colitis and in a much smaller percentage of the sera of patients with Crohn's disease (44). Patients with primary sclerosing cholangitis with or without IBD also had PANCA. Although antineutrophil cytoplasmic antibodies are extensively used in diagnosing vasculitic diseases for many years, presence of PANCA (mainly in ulcerative colitis) is intriguing and needs further studies to identify the immunoreactive antigen(s).

Ulcerative colitis colon-bound antibody and colin epithelial Mr $40 \mathrm{~K}$ protein: A colonic tissue-bound antibody of IgG isotype has been isolated and characterized from patients with ulcerative colitis and 'colitis colonbound antibody' or CCA-IgG (45). Using immunotransblot technique, the authors detected a $\mathrm{Mr} 40 \mathrm{~K}$ protein in the extracts of colonic tissue that is specifically recognized by the CCA. IgG obtained from ulcerative colitis colon (18). Autologous CCA-IgG also reacted with the $\mathrm{Mr} 40 \mathrm{~K}$ protein, further demonstrating the autoantigenicity of the protein (18). However, it was not recognized by IgG eluted from Crohn's colitis or other control IgG, The Mr 40K protein was found in both diseased and normal colon but was ab. sent in human ileum, duodenum, stomach and liver, suggesting organ specificity of the antigen.

These studies indicate that the Mr $40 \mathrm{~K}$ protein is a normal colonic antigen, and CCA-IgG eluted from colonic tissue seems to be specific to ulcerative colitis patients and represents an 'autoantibody' against the colon specific tissue protein.

The $\mathrm{Mr} 40 \mathrm{~K}$ protein was highly enriched, and subsequently murine monoclonal antibodies against the protein were developed (46). Using one of the monoclonal antibodies designated $7 \mathrm{E} 12 \mathrm{H} 12$, the $\mathrm{Mr} 40 \mathrm{~K}$ protein was localized to colonic epithelial cells and not in 13 other epithelial organs, including the small intestinal enterocytes and stomach (46). These results indicated epithelial origin of the protein and confirmed an earlier observation of the organ specificity of the $\mathrm{Mr} 40 \mathrm{~K}$ protein, as shown by immunotransblot analysis (18). The immunoreactivity was local. ized on the plasma membrane mostly along the basolateral surface and apical domain of the colonic epithelial cells. A majority of the patients with ulcerative colitis have circulating antibodies to the colon extract enriched in the $\mathrm{Mr}$ $40 \mathrm{~K}$ protein further suggesting its nature as an autoantigen (47).

The $\mathrm{Mr} 40 \mathrm{~K}$ protein is distributed 
nonuniformly in the colon with minimum expression (mainly in goblet cells) in the cecum/ascending colon, to more intense and diffuse distribution in all colonocytes in the rectum (48). This intriguing distribution may be relevant to the rectal involvement in almost all patients with ulcerative colitis. Additional support for the potential value of this colonic autoantigen is provided by presence of cross-reactive unique epitope(s) in the extraintestinal organs such as skin and biliary epithelium (49), and more recently in ciliary body and joints (50), the locations which match perfectly the sites of clinical manifestation outside the colon (Figure 2).

Antibody-dependent cell-mediated cytolysis and complement activation (Figure 3): There is some evidence that anticolon antibodies present in the sera from patients with ulcerative colitis but not Crohn's disease may injure epithelial cells by ADCC $(17,20)$. The ADCC correlated with disease activity and disappeared after total colectomy (17). Both polyclonal and monoclonal anti-Mr 40K antibodies can block the ulcerative colitis sera-induced ADCC, demonstrating that the $\mathrm{Mr} 40 \mathrm{~K}$ as-

\section{REFERENCES}

1. Broberger O, Perlmann P. Autoantibodies in human ulcerative colitis. J Exp Med 1959;110:657-74.

2. Elson C. The immunology of inflammatory bowel disease. In: Kirsner JB, Shorter G, eds. Inflammatory Bowel Disease. Philadelphia:Lea \& Febiger, 1988:97-164

3. MacDermott RP, Stenson WE. Alterations of the immune system in ulcerative colitis and Crohn's disease. Adv Immunol 1988;42:285-328.

4. Fiocchi C. Overview of inflammatory bowel disease pathogenesis. Can J Gastroenterol 1990;4:309-16.

5. Deusch K, Reiter C, Mauthe B, Riethmuller G, Classen M. Chimeric monoclonal anti-CD4 antibody therapy proves effective for treating inflammatory bowel disease. Gastroenterology 1992;102:A615. (Abst)

6. Dear AS, Fuggle SV, Fabre JW, et al. The detailed distribution of MHC class Il antigens in normal human organs. Transplantation 1984;38:293-8.

7. Selby WS, Janossy G, Mason DW, et al. Expression of HLA-DR antigens sociated epitope(s) is one of the target proteins $(51,52)$. Recent studies also showed that the Mr $40 \mathrm{~K}$ protein expression is increased by lymphocyte-derived cytokine, gamma interferon (53), that can also increase class II MHA molecule expression in the intestinal epithelial cells (54). Such amplifications of both $\mathrm{Mr} 40 \mathrm{~K}$ protein and class II molecules on colonic epithelium may be important in the autoimmune reaction in ulcerative colitis.

Using 3 colour immunofluorescence technique, Halstensen et al (48) demonstrated that $\mathrm{Mr} 40 \mathrm{~K}$ antigen epitope co-localizes with the $\operatorname{lgG}$, antibody along with activated complement products, suggesting an $\mathrm{Mr} 40 \mathrm{~K}$ antigen mediated local autoimmune injury in ulcerative colitis. In further support of the postulated IgGl-mediated attack on the $\mathrm{Mr} 40 \mathrm{~K}$ colonic autoantigen as an important immunopathologigal feature of ulcerative colitis, a recent finding demonstrated that peripheral blood lymphocytes from ulcerative colitis patients (but not controls) and lamina propria lymphocytes from mucosal biopsy specimens from ulcerative colitis spontaneously released IgGl-antibodies to an antigen enriched in the

by colonic epithelium in inflammatory bowel disease. Clin Exp Immunol 1983;53:614-8.

8. Hirata I, Austin LL, Blackwell WH, et al. Immunoelectron microscopic localization of HLA-DR antigen small intestine and colon in control and in inflammatory bowel disease. Dig Dis Sci 1986;31:1317-30.

9. Shenfeld Y, Schwartz RS. Immunologic and genetic factors in autoimmune diseases. N Engl J Med 1984;311:1019-29

10. Klein GL, Ament ME, Sparks RS. Monozygotic twins with Crohn's disease. Gastroenterology 1980;79:931-3.

11. Elson CO, Kagnoff MF, Fiocchi C, Befus AD, Targan S. Intestinal immunity and inflammation: Recent progress. Gastroenterology 1986;91:746-68.

12. Rotter Jl, Wang S-J, Yang $\mathrm{H}$, et al. Genetic heterogeneity between ulcerative colitis and Crohn's disease identified by molecular HLA class II association. Gastroenterology 1992;102:A688. (Abst)

13. Fiocchi C, Roche JK, Michener WM. High prevalence of antibodies to
Mr 40K protein (55). Furthermore, $82 \%$ of 111 patients with ulcerative colitis had serum $\operatorname{IgGi}$ antibodies to this antigen preparation, whereas only $12 \%$ of Crohn's disease patients and none of the other controls were positive (56). Circulating antibodies to the enriched $\mathrm{Mr} 40 \mathrm{~K}$ colon extract was also seen in the cotton-top tamarins as these animals spontaneously develop ulcerative colitis-like colitis (57).

Future studies focusing on the identification of the antigenic epitopes in the epithelial cell associated protein(s) and their humoral and cellular immunological responses, crossreactivity of the epitope(s) to other organs known to be involved in IBD, and to the bacterial and viral proteins (molecular mimicry), will lead to further understanding of the autoimmunity and development of novel approaches of therapy in IBD.

ACKNOWLEDGEMENTS: This work is supported in part by a research grant NIAD. DK R01 DK 44314.01 from the National Institute of Health, Bethesda, Maryland and Baxter Healthcare Corporation. We also wish to acknowledge excellent secretarial assistance from Ms Rochelle K. Golub.

intestinal epithelial antigens in patients with inflammatory bowel disease and their relatives. Ann Int Med 1989:110:786-94.

14. Lagercrantz R, Hammarstrom S, Perlmann P. Gustafsson BE. Immunological studies in ulcerative colitis. 3. Incidence of antibodies to colon-antigen in ulcerative colitis and other gastrointestinal diseases. Clin Exp Immunol 1966;1:263.

15. Marcussen H, Nerup J. Fluorescent anti-colon and organspecific antibodies in ulcerative colitis. Scand J Gastroenterol 1973:8:9.

16. Marcussen H. Fluorescent anti-colonic and $E$ coli antibodies in ulcerative colitis. Scand J Gastroenterol 1978;13:277.

17. Das EK, Kadono Y, Fleischer GM. Antibody-dependent cell-mediated cytotoxicity in serum samples from patients with ulcerative colitis. Am ] Med 1984:77:791-6.

18. Takahashi F, Das KM. Isolation and characterization of a colonic autoantigen specifically recognized by colon tissue-bound IgG from idiopathic ulcerative colitis. J. Clin Invest 1985;76:311-8. 
19. Hibi T, Toda K, Hara A, et al. In vitro anticolonic antibody production by muscular or peripheral blood lymphocytes from patients with ulcerative colitis. Gut 1990;31:1371-6.

20. Auer IO, Grosch L, Hardorfer C, Roder A. Ulcerative colitis specific cytotoxic $\operatorname{IgG}$-autoantibodies against colonic epithelial cell. Gut 1988;29:1639-47.

21. MacDermott RP, Nash GS, Auer IO, et al. Alterations in serum immunoglobulin G subclasses in patients with ulcerative colitis and Crohn's disease. Gastroenterology 1989;96:764-8.

22. Halstensen TS, Mollnes TE, Garred P, Fausa O, Brandtzaeg P. Epithelial deposition of immunoglobulin Gl and activated complement ( $\mathrm{C} 3 \mathrm{~b}$ and terminal complement complex) in ulcerative colitis. Gastroenterology 1990;98:1264-71.

23. Halstensen TS, Mollnes TE, Garred P, Fausa O, Brandtzaeg P. Surface epithelium-related activation of complement differs in Crohn's disease and ulcerative colitis. Gut. (In press)

24. Fulpius BW, Lefvert AK, Cuenoud S, Mourey A. Properties and serum levels of specific populations of antiacetylcholine receptor antibodies in myasthenia gravis. Ann NY Acad Sci 1981;377:307-15.

25. Shechter Y, Maron R, Elias D, Cohen IR. Autoantibodies to insulin receptor spontaneously develop as antiidiotypes in mice immunized with insulin. Science 1982;216:542-4.

26. Urban JL, Kumar V, Kono DH, et al. Restricted use of $\mathrm{T}$ cell receptor $\mathrm{V}$ genes in murine autoimmune encephalomyelitis raises possibilities for antibody therapy. Cell 1988;54:577-92.

27. Zanetti M, Mampaso F, Wilson CB. Anti-idiotype as a probe in the analysis of autoimmune tubulointerstitial nephritis in the brown Norway rat. J Immunol 1983;131:1268-73.

28. Oldstone MBA. Molecular mimicry and autoimmune disease. Cell 1987;50:819-20.

29. Kagnoff MA, Austin RK, Hubert JJ. Possible role for a human adenovirus in the pathogenesis of celiac disease. J Exp Med 1984;160:1544-7.

30. Schwimmbeck PL, Yu DTY, Oldstone MBA. Autoantibodies to HLA B27 in the sera of HLA B27 patients with ankylosing spondylitis and Reiter's syndrome. J Exp Med 1987;166:173-81.

31. Fenderson PG, Fischetti VA, Cunningham MW. Tropomyosin shares immunologic epitopes with group A streptococcal $\mathrm{M}$ proteins. J Immunol 1989;142:2475-81.

32. Roche JK, Fiocchi C, Youngman K.
Sensitization to epithelial antigens in chronic mucosal inflammatory disease. Characterization of human intestinal mucosa-derived mononuclear cells reactive with purified epithelial cell-associated components in vitro. J Clin Invest 1985;75:522-30.

33. Bhatt BD, Ebert EC, Dasgupta A, Das KM. Mr 40,000 colonic protein induces proliferative response in peripheral blood lymphocytes (PBL) from patients with ulcerative colitis. Gastroenterology 1990;98:A439. (Abst)

34. Perlmann P, Broberger O. In vitro studies of ulcerative colitis. II. Cytotoxic action of white blood cells from patients on human fetal colon cells. J Exp Med 1963;117:717.

35. Watson DW, Quigley A, Bolt RJ. Effect of lymphocytes from patients with ulcerative colitis on human adult colon epithelial cells. Gastroenterology 1966;51:985.

36. Shorter RG, Spencer RJ, Huizenga KA, Hallenbeck GA. Inhibition of in vitro cytotoxicity of lymphocytes from patients with ulcerative colitis and granulomatous colitis for allogenic colonic epithelial cells using horse antihuman thymus serum.

Gastroenterology 1968;54:227.

37. Stobo JD, Tomasi TB, Huizenga KA, Spencer RJ, Shorter RG. In vitro studies of inflammatory bowel disease. Surface receptors of the mononuclear cell required to lyse allogeneic colonic epithelial cells. Gastroenterology 1976;70:171.

38. Shorter RG, McGill DB, Bahn RC. Cytotoxicity of mononuclear cells for autologous colonic epithelial cells in colonic diseases. Gastroenterology 1984;86:13.

39. Kemler BJ, Alpert E. Inflammatory bowel disease: Study of cell mediated cytotoxicity for isolated human colonic epithelial cells. Gut 1980;21:353.

40. Manzione NC, Bagchi S, Das KM. Demonstration of Crohn's disease tissue-specific proteins by enzyme-linked immunosorbent assay (ELISA). Dig Dis Sci 1987;32:593-7.

41. Bagchi S, Das KM. Detection and partial characterization of Crohn's disease tissue-specific proteins by Crohn's disease sera. Clin Exp Immunol 1984;55:41-8.

42. Bagchi S, Baral B, Das KM. Isolation and characterization of Crohn's disease tissue specific glycoproteins. Gastroenterology 1986;91:326-32.

43. Das PK, Kreuzpainter G, Stronkhorst A, Tytgat G. Antibody response to mycobacterial 45/48KDa doublet antigen in Crohn's patients: A retrospective ELISA serology. Gastroenterology 1992;102:A612. (Abst)
44. Duerr RH, Targan SR, Landers CJ, et al. Neutrophil cytoplasmic antibodies: A link between primary sclerosing cholangitis and ulcerative colitis. Gastroenterology 1991;100:1385-91.

45. Das KM, Dubin R, Nagai T. Isolation and characterization of colonic tissue-bound autoantibodies from patients with idiopathic ulcerative colitis. Proc Natl Acad Sci USA 1978;75:4528-32.

46. Das KM, Sakamaki S, Vecchi M, Diamond $\mathrm{B}$. The production and characterization of monoclonal antibodies to human colonic antigen associated with ulcerative colitis: Cellular localization of the antigen by using the monoclonal antibody. J Immunol 1987;139:77-84.

47. Takahashi F, Shah HS, Wise LS, Das KM. Circulating antibodies against human colonic extract enriched with a $40 \mathrm{kDa}$ protein in patients with ulcerative colitis. Gut 1990;31:1016-20

48. Halstensen T, Das KM, Brandtzeag P. Epithelial deposits of immunoglobulin G1 and activated complement colocalize with the Mr. $40 \mathrm{KD}$ putative autoantigen in ulcerative colitis. Gut 1993. (In press)

49. Das KM, Vecchi M, Sakamaki S. A shared and unique epitope(s) on human colon, skin, and biliary epithelium detected by a monoclonal antibody. Gastroenterology 1990;98:464-9.

50. Bhagat S, Bamdad M, Das KM. A common epitope shared by human colon, eye and joint tissue detected by a monoclonal antibody (7E.H., IgM isotype). Gastroenterology 1992;102:A595. (Abst)

51. Das KM, Sakamaki S, Vecchi M. Ulcerative colitis: Specific antibodies against a colonic epithelial $\mathrm{Mr} 40,000$ protein. Immunol Investig 1989;18:459-72.

52. Biancons L, Ebert E, Das KM. The Mr 40,000 colonic protein is associated with antibody dependent cellmediated cytolysis (ADCC) by ulcerative colitis (UC) sera. Gastroenterology 1990;98:A159. (Abst)

53. Das KM, Squillante L, Robertson F. Expression of the $40 \mathrm{kD}$ protein in DLD-1 colon cancer cells and the effect of cytokines. Clin Exp Immuno 1992;88:138-42.

54. Mayer L, Shlien R. Evidence for function of la molecules on gut epithelial cells in man. J Exp Med 1987;166:1471-83.

55. Biancone L, Dasgupta T, Paoluzi OA. DiPaolo MC, Pallone F, Das KM. Lamina propria cells from colonic mucosal biopsy specimens of patients 
with ulcerative colitis secrete $\mathrm{IgGl}$ antibodies that recognize colonic protein(s) enriched with the Mr 40K protein. Gastroenterology 1992;102:A595. (Abst)

56. Das KM, Mandal A, Dasgupta A. Sera from patient with ulcerative colitis contain $\mathrm{IgGl}$ autoantibodies against the colonic protein(s) highly enriched with the $\mathrm{Mr} 40 \mathrm{~K}$ protein.

Gastroenterology 1992;102:A612. (Abst)

57. Das KM, Vecchi M, Squillante L, Dasgupta A, Henke M, Clapp N.
Mr 40,000 human colonic epithelial protein: Its expression in colonic mucosa and presence of circulating anti-Mr 40,000 antibodies in cotton top tamarins with spontaneous colitis. Gut 1992;33:48-54. 


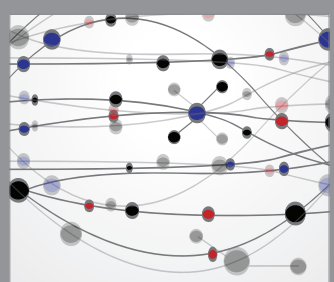

The Scientific World Journal
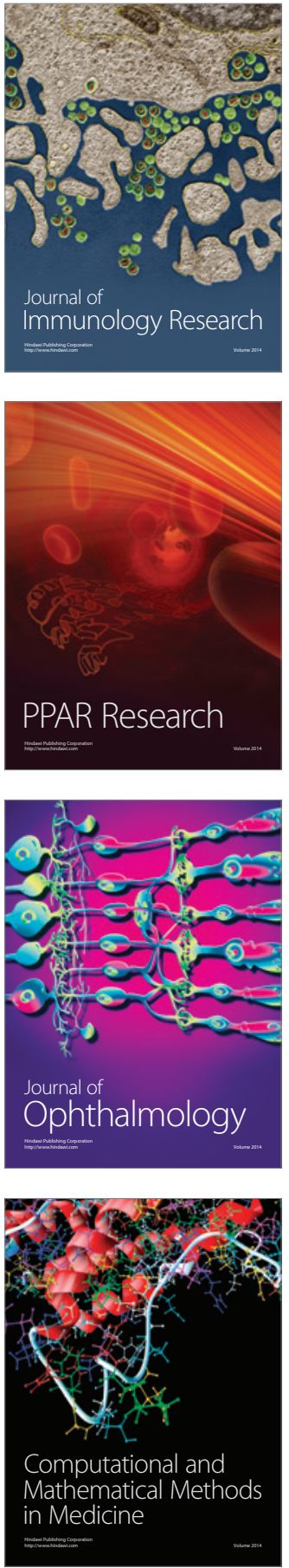

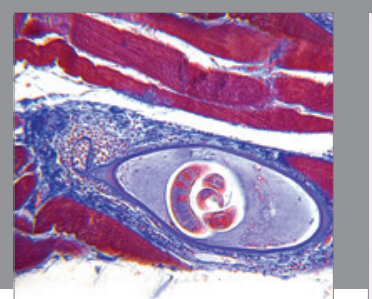

Gastroenterology Research and Practice

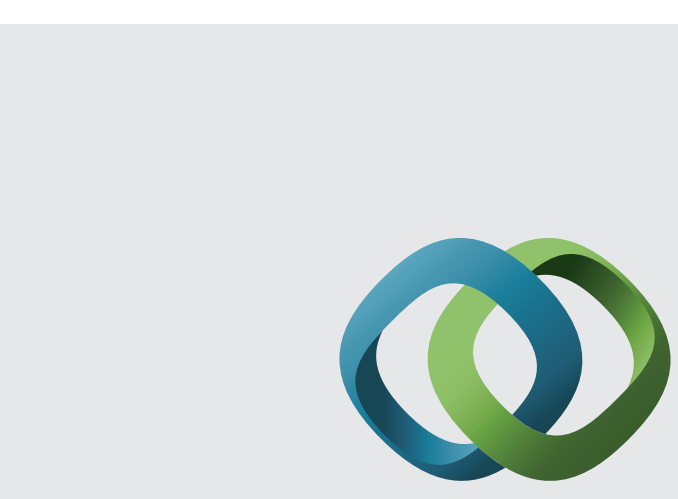

\section{Hindawi}

Submit your manuscripts at

http://www.hindawi.com
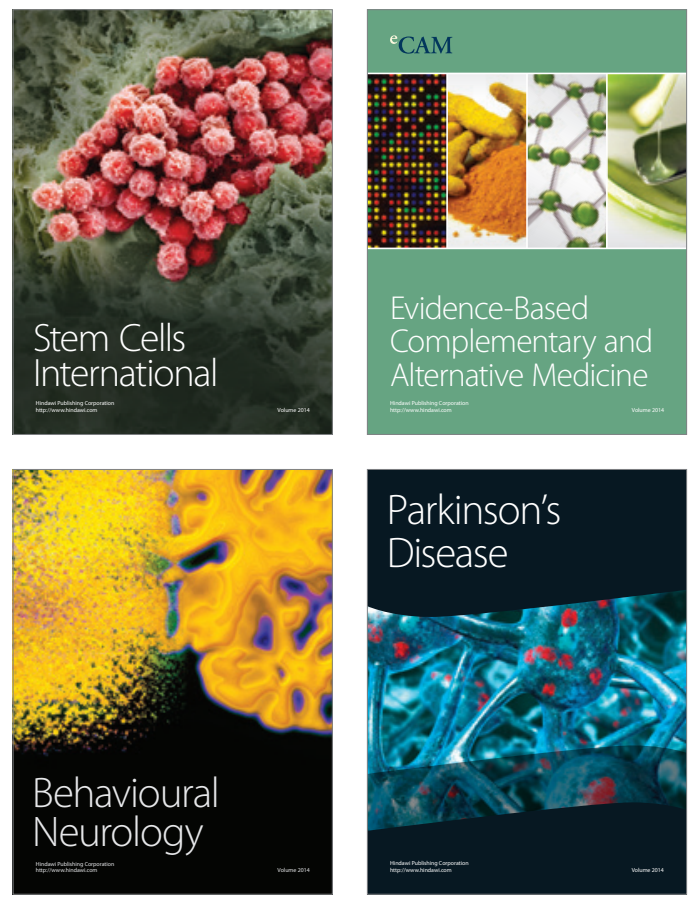
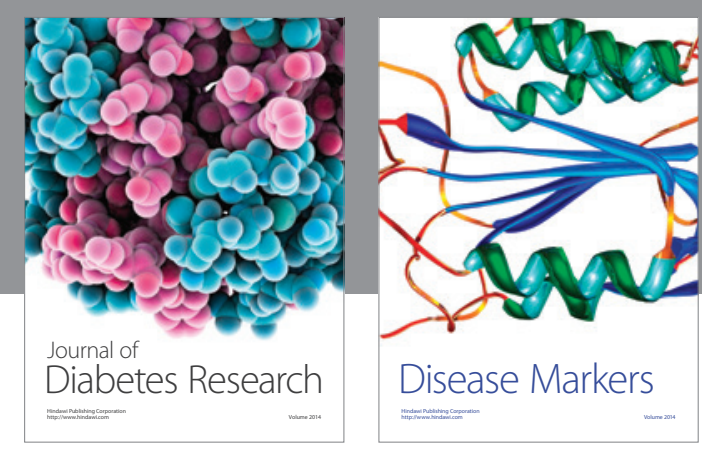

Disease Markers
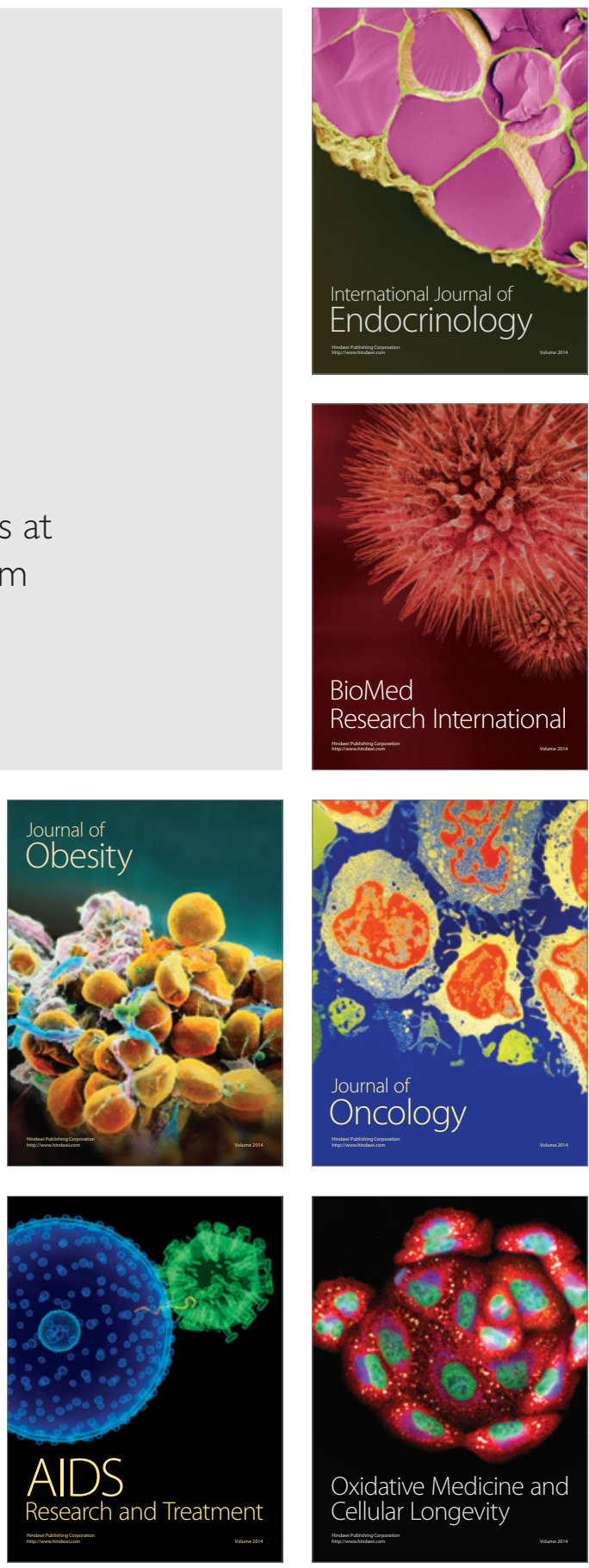